\title{
Chinese industrialization from the New-Developmental perspective
}

\author{
A industrialização chinesa sob a \\ perspectiva do novo desenvolvimentismo
}

LUÍS FELIPE LOPES MILARÉ*,**

\begin{abstract}
RESUMO: O objetivo deste artigo é apresentar uma síntese do processo de industrialização chinesa e avaliar se o novo desenvolvimentismo é adequado para explicar a transformação na estrutura produtiva daquele país. Para tanto, será apresentada brevemente a teoria novo-desenvolvimentista e, posteriormente, o processo histórico de formação da indústria chinesa, expondo os pontos de convergência identificados. Observou-se que a teoria é adequada para se entender/interpretar esse processo de rápido crescimento.

PALAVRAS-CHAVE: Novo desenvolvimentismo; industrialização chinesa.
\end{abstract}

ABSTRACT: The main objective of this paper is to present a synthesis of the Chinese industrialization and evaluate if the New-Developmental Theory is capable of explaining the transformation in its industrial structure. In order to do so, first will be presented a brief review of the New-Developmental Theory; next, through a historical perspective, we'll describe the Chinese industrialization exposing the convergence points with the theory. Finally, we conclude that the theory is adequate to explain the success of the Chinese industrialization. KEYWORDS: New developmentalism; Chinese industrialization.

JEL Classification: O11; 014; O25; O40.

New Developmentalism, as an economic strategy, is an alternative to economic liberalism for middle-income countries in their pursuit for economic development. As a theory is a generalization of the successful growth experiences of Brazil, mainly in the 1970s, and of the East Asian countries from the 1950s to today. It sustains that after the formation of nation-states, keeping the five macroeconomic prices interest rate, level of wages, inflation rate, profit rate and exchange rate - is a necessary condition for a country to achieve its structural change. Also, for the New-

\footnotetext{
* Luís Felipe Lopes Milaré is master in economics by Universidade Federal de São Carlos, Sorocaba/SP, Brasil. E-mail: luismilare@gmail.com. Orcid: https://orcid.org/0000-0002-1038-3186.

* * I thank professor Luiz Carlos Bresser-Pereira for his very helpful comments. Submitted: 15/April/2019; Approved: 18/June/2019.
} 
-Developmental Theory, public investment plays a strategic role in the growth process, while private investment depends on the expected rate of profit and the effective; when the exchange rate is overvalued in the long-term, as it is common in developing countries, the competent companies do not have access to this demand and are discouraged to invest. As part of the development process, the theory suggests that a country should achieve sustained increase in wages while keeping satisfying the expected profit rate of the companies in the manufacturing industry.

The purpose of this paper is to present an overall picture of the most significant industrialization process of recent decades - the Chinese industrialization - and to analyze whether the New-Developmental Theory is adequate to explain the expressive structural change experienced by the country. In order to do so, I will initially present a brief summary of the theory; next, through a historical perspective of the Chinese industrialization, I'll analyze possible points of convergence between this process of industrialization and New-Developmental Theory. Since the economists associated to this approach say that it is based in successful East Asian experience, the answer to this question is in principle positive.

In spite the risk of presenting the New-Developmental Theory superficially in only a few pages, I consider that it is necessary to present at least some of the main concepts of the theory before starting the analysis on the Chinese industrialization ${ }^{1}$. Considering that this paper aims to discuss if the New-Developmental Theory is adequate to explain the structural change experienced in China, these concepts will guide us through this paper in order to understand if they were important for the Chinese industrialization.

The theoretical framework of the New Developmentalism was created in other to guide middle-income countries on their catching-up process. Thus, it would be considered a prerequisite for the application of the theory that the country has already formed their nation-state, has held their primitive accumulation and their industrial/capitalist revolutions (Bresser-Pereira, 2017a).

Once a country reaches this stage of development it would be state's responsibility to guarantee that their industry would be capable to compete in the global market with rich countries in equivalent conditions. The theory suggests that, nowadays, there is the global competition between companies but there is also a competition between nation-states on which, each country tries to secure their conditions to growth. In other words, even developed countries that disseminate the idea that the free market is the best institution to promote sustainable growth, do interferes in their economy to guarantee better conditions for their companies to compete in the global market.

In that way, there is no alternative, either developing countries competes with rich ones on an equal footing or they will get subordinated. Therefore, for a midd-

\footnotetext{
${ }^{1}$ For a better understanding of theoretical framework of the New Developmentalism, please see BresserPereira (2019), Bresser-Pereira (2017a), Bresser-Pereira (2017b) and Bresser-Pereira, Oreiro and Marconi (2016).
} 
le-income country to be able to enter the global market in a competitive way, it would be the nation-states responsibility to guarantee the conditions for its companies to face this competition fairly. But how could a middle-income country secure these conditions? The New-Developmental Theory suggests that they must attempt to get their five macroeconomic prices "right", as Bresser-Pereira explains:

New developmental macroeconomics is interested in the five macroeconomic prices, which should be the "right" prices: (a) the rate of profit should be satisfactory for firms to invest; (b) the level of the interest rate around which the central bank conducts monetary policy should be low, corresponding to neutral or natural level, i.e., the international basic interest rate plus no more than two percentage points; (c) the exchange that should make competitive the companies using technology in the state of the art world; (d) the wage rate should be compatible with a satisfactory rate of profit and should grow with increased productivity; and (e) the rate of inflation should be low (Bresser-Pereira, 2017a, p. 10).

Although New Developmentalism views industrial policy as an important instrument for middle-income countries in their catching-up process, the theory doesn't put it in first place, but as a complement to the adequacy of the five macroeconomic prices. Since middle-income countries have already made their industrial revolutions, protectionism based on the infant industry wouldn't apply either. So, the theory proposes that industrial policy must be done by middle-income countries in their catching-up process - even because developed countries still conducts a lot of industrial policy -, but what really defines a theory as new-developmental is whether it gives a central role to the five macroeconomic prices or not.

Guaranteeing that these prices are "right" would level the playing field for the companies in developing countries to compete with developed nations on equal conditions. We say that these prices must be kept right by the nation-states because the market will not do it by itself. That happens for a number of reasons, but the most important one is that middle-income countries have a tendency to a cyclical and chronic overvaluation of the exchange rate, due to the habitual policy of setting high interest rates to attract capitals and, when the country suffers from the Dutch disease, due to the fact that the country does not recognize that and fail to adopt policies to neutralize the disease ${ }^{2}$. Without the five macroeconomic prices adjusted, middle-income countries wouldn't be able to compete with developed nations fairly. Based on this brief summary of the New-Developmental Theory, we may now analyze the Chinese industrialization.

\footnotetext{
${ }^{2}$ Many countries intuitively neutralized the Dutch disease on the domestic market by setting high import tariffs on manufactured goods; when, from the 1980s, they engaged in trade liberalization, they dismounted this mechanism without having conscience of what they were doing. The outcome was deindustrialization and low growth.
} 
Many authors, when analyze the Chinese industrialization, starts their studies in 1978 with the rise to power of Deng Xiaoping. It's true that after 1978 China started a series of reforms to open the economy and accelerated their catching-up, with constant gain in productivity and an astounding growth rate of $10 \%$ p.y. However, I suggest that the Chinese industrialization started before, with Mao Zedong (1949-1976), because it was in this period that China created their nation-state, realized their primitive accumulation and created a heavy industry.

Before the rise of Mao Zedong to power, the Chinese society was marked by a traditional inaction and colonialism. The society by that time could be described as divided into clans, with great social fragmentation, a strict separation of classes and no social mobility. Families who migrated from the countryside to the city remained socially and economically apart of each other, keeping relations exclusively with their clan of origin, so that the cities became mere administrative districts without political and economic cohesion (Leão, 2010). On the other hand, since the Opium War (1856-60), China was reduced to the colonial condition and faced a century of decadency.

The rise to power of Mao Zedong with the Communist revolution of 1949 happened with great legitimacy. By that time, China was devastated by the two recent wars - against the Japanese and the nationalists -; agriculture had been ruined and the reduced industry existing was destroyed. In this context, Mao Zedong raised to power and was able to unite the Chinese people around a same goal: the land reform. Since the economy was largely dependent on agriculture with $80 \%$ of the population in the countryside and more than half of GDP coming from the primary sector - in order to proceed with the industrialization it was necessary to create an agricultural surplus, capable of supplying the city with food and raw materials for the infant industry (Milaré \& Diegues, 2012).

The land reform intended by Mao Zedong had the objective to reduce inequalities, but also to fast expand the primary sector. The land reform carried out ended up been extensive: it transferred about half the cultivated land to 300 million peasants who had no property. In addition, several farms and state-owned farms were organized, allowing peasants to become employees.

The reform had the objective of organizing the economy towards industrialization; in this way, the government was not limited to distributing land. For Mao Zedong, the revolutionary impetus should be continuous. A revolution should succeed another, so that the society wouldn't return to immobility of the Empire. A few years after the agrarian reform, many others followed: in the countryside, farmers were organized in cooperatives and the state started to control production through their state agencies. In a short time, the exchanges by private agents were eliminated and the Government became the only distributor of agricultural products. In the cities, Chinese Communist Party had also initiated a series of reforms, abolishing the previously existing bourgeoisie and forcing private companies to work under "contract" with state departments, from which they received credit 
and raw materials. The Chinese state obligated the existing industry to merge with state companies, so that in a short period the government controlled all the production and invested a lot in the formation of a heavy industry (Pagotto, 2006).

This strategy was directly aligned to the goal of the five-year plan to increase production and create a heavy industry. Maybe that's the greatest legacy left by Mao Zedong. In addition to unite Chinese people around a common goal (agrarian reform), he was able to create a heavy industry that although wasn't very modern for its time, was robust enough to create the bases for the Deng Xiaoping's catching-up process.

Table 1 shows the composition of the economic sectors in GDP. While in 1952 agriculture represented more than $50 \%$ of GDP and the industry represented only $176 \%$; when Deng Xiaoping ascended to power in 1978, the Chinese productive structure had been completely changed: industry already accounted for more than $44 \%$ of GDP.

Table 1: Composition of Gross

Domestic Product (\%), selected years

\begin{tabular}{ccccc}
\hline Year & $\begin{array}{c}\text { Primary sector } \\
\text { (agriculture) }\end{array}$ & \multicolumn{2}{c}{ Secondary sector } & $\begin{array}{c}\text { Tertiary } \\
\text { sector }\end{array}$ \\
\hline 1952 & 50.5 & 17.6 & 3.2 & 28.6 \\
1955 & 46.3 & 21.0 & 3.4 & 29.3 \\
1960 & 23.4 & 39.0 & 5.5 & 32.1 \\
1965 & 37.9 & 31.8 & 3.2 & 27.0 \\
1970 & 35.2 & 36.8 & 3.7 & 24.3 \\
1975 & 32.4 & 41.5 & 4.2 & 21.9 \\
1978 & 28.1 & 44.3 & 3.8 & 23.7 \\
\hline
\end{tabular}

Source: Own elaboration from China Statistical Yearbook, 1999.

The analysis of Mao Zedong's Era shows that it was on this period that China reached what could be called the "prerequisites" to make its capitalist revolution: the country already has formed its nation-state, made its primitive accumulation, and industrialized. During Mao Zedong's Era, China was able to (1) unite the Chinese people around a goal (land reform) and form their nation-state; (2) the country also could guarantee their primitive accumulation through land reform organizing the production and investing -; and, finally, (3) it was during this period that China made their industrial revolution evidenced by the high participation of industry in GDP, shifting from $17.6 \%$ to $44.3 \%$. 
New Developmentalism defends the integration between the two most important institutions in capitalism: state and market. The theory argues that the market is more efficient to coordinate competitive companies and should be encouraged. The theory also suggests that protectionism based on the argument of the infant industry should be rejected, because middle-income countries have already made their industrial revolutions and have created an industrial structure. So what middle-income countries need is not protectionism, but levelling the playing field so that their industry can compete on equal conditions with the most modern and developed companies in the world. It's important to notice that the protection of the domestic industry through subsidies or exorbitant import tax rates could create incentives for inefficiency. Therefore, the correct way to ensure industrial competitiveness is through the adequacy of five economic prices, in particular the exchange rate. After this adjustment, industrial policy can - and must - be used to encourage the development process; however, only industrial policy without the adequacy of the five macroeconomic prices won't guarantee equal conditions to compete and, therefore, won't drive middle-income countries to a development process.

The articulation between state and market is aligned with the first major reform undertaken by Deng Xiaoping: the "un-collectivization" of the agriculture, through a system of contracts, known as "bao gan dao bu". In this new system of contracts peasants were no longer obliged to deliver all of their production to the Government and to produce according to the centralized planning. Only a part of the production would need to be sold to the state and another part could be freely traded. This reform created the possibility to privatize the gains of the work, so peasants began to diversify and expand their production. It is true that in the Mao Zedong's Era, collectivization of the countryside was essential to create a more egalitarian society, solve the problem of hunger and increase production. However, it is also true that the logic of market put by Deng Xiaoping contributed to a further increase in industrial productivity (Milaré \& Diegues, 2015).

Once again the reforms were not limited to agriculture. In the cities, company's known as Township and Village Enterprises (TVEs) also started to respond directly to market. In the Maoist period, these companies were created exclusively to supply the agricultural demand, based on the priority defined by central government with great restrictions for its creation and operation. The TVEs were, in the Maoist period, only local government's proprieties. With Deng Xiaoping, rules to create TVEs were attenuated, and so did their way of doing business: now they could respond directly to market incentives and could perform in the niches that they understood that would be more profitable. Since they could meet market demands, there was a strong increase in production as well as in diversification of the products. This strategy went so well that some authors even say that TVEs were an essential element for the reorganization of social division of labor and that they 
were the most dynamic part of Chinese economy between 1978 and 1990 (Jabbour \& Dantas, 2017; Masiero, 2006).

In addition to TVEs, the state-owned enterprises (SOEs) also started responding to market incentives: they expanded credit systems, stimulated expansion of exports through state-trading companies and created mechanisms that would associate worker's marginal productivity to its salary. With these reforms SOEs were responsible for creating large multinationals capable of competing internationally. They had the goal of keeping high levels of investment and direct their efforts to produce more technologically advanced goods (Milaré \& Diegues, 2015).

Allowing market incentives to work with the coordination of nation-state is known as a key factor for the success of Chinese industrialization. But there is a second very important point that should be brought into discussion: the geopolitical context on which the reforms took place. It was on a very favorable context marked by the rapprochement with the United States that on 1972 eliminated the embargo on China and opened their market for Chinese products, granting them with most-favored-nation treatment (Medeiros, 1999). In this way, China has gained access to the huge United States market, as well as access to international credit, as Medeiros proposes:

Chinese opening was preceded by a fast access to international financing in exceptionally favorable conditions. According to Barnett (1981), China obtained in 1979, by the Government of Japan, interest rates of $7.25 \%$ p.y. for loans above 5 years, a rate lower than the recommended by the OECD to developing countries. After various agreements China contracted in 1979 loans between \$30 billion and \$20 with Governments or by export-import banks guaranteed by governments. There was a pool of Governments to grant 18 billion of loans in 1980: where 7 came from French banks, 5 from British and 2 from Japanese banks (Medeiros, 1999, p. 99, own translation).

Based only on this information, one might think that Chinese industrialization was a result of a strategy of growing with "foreign savings". Add to that the fact some economists suggest that foreign direct investment (FDI) had a central role to the expansion of productive capacity. However, it is necessary to distinguish FDI from current account deficits or foreign savings. In China's growth since 1980 FDI played an effective although limited role, but China did not "grow with foreign savings". Analyzing the data of FDI over gross fixed capital formation (Figure 1), we'll see that throughout the period of accelerated growth, FDI participation in gross fixed capital formation was, on average, only $7 \%$. This indicates that FDI did not have a decisive role in the expansion of production capacity, although it had a key role for technology absorption and to promote exports. The technology transfer happened mainly because, for a long period, foreign companies could only enter in the Chinese market through joint-ventures with national groups. These joint-ventures enabled not only that the "state of the art" of technology were 
employed in Chinese factories, but also that in a few years national groups could internalize this knowledge to continue autonomously with their own process of technological sophistication.

Figure 1: Foreign Direct Investment over Gross Fixed Capital Formation (FDI/GFCF)

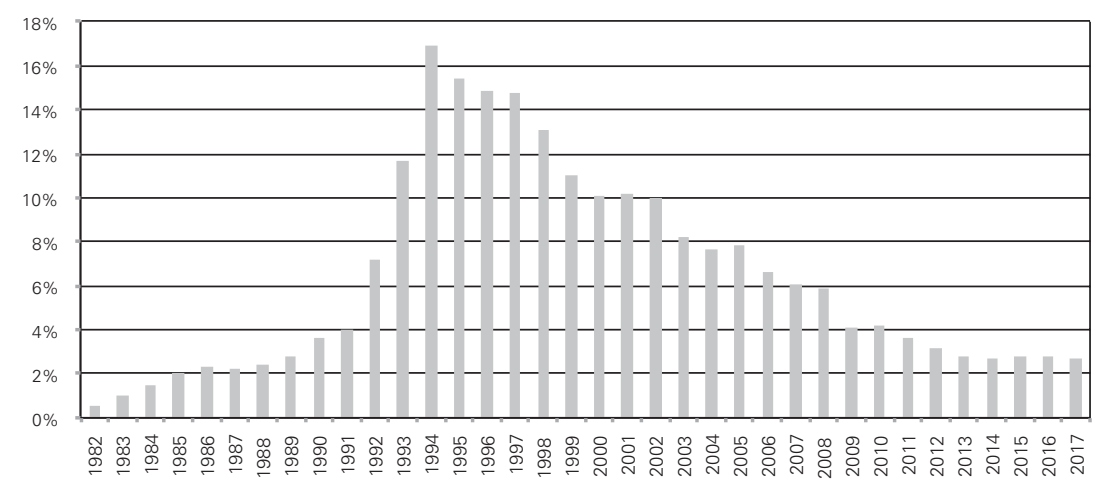

Source: Own elaboration from UnctadStat (2019).

On the other hand, is also important to notice that even though the Chinese Government took international loans to finance their import of machinery and equipment to upgrade their industry, they did not adopt the strategy of growing with external savings. What is observed in Figure 2 is that, during the whole period (1982-2017), China recorded a surplus trajectory in its balance of current transactions, incurring in deficits only in five years.

This analysis shows another similarity between what proposes the New-Developmental Theory and Chinese industrialization. The theory suggests that middle-income countries do not need foreign capital and should not incur in current account deficits to be financed by foreign savings (Bresser-Pereira \& Gala, 2008). In these countries a current-account deficit pushes their currency to an appreciated basis; an appreciated exchange rate results on loss of competitiveness for competent firms installed in the country, making it harder for them to have accesses to the existing domestic and foreign demand. At the same time, appreciated exchange rate stimulates consumption, since it increases real wages and the incomes of rentier-financier (interest, rents and dividends). In this way, the inflow of external saving commonly replaces domestic savings, appreciating the exchange rate without promoting an increase on investments ${ }^{3}$. It also disconnects competent firms from global market, weaken the industry installed in the country and remove the incentive for medium/long term investment. What we have seen in China was the country's decision to not grow with foreign savings, exactly what proposes New-Developmental Theory.

\footnotetext{
${ }^{3}$ For more details on why middle-income countries shouldn't use foreign capital to grow, please see Bresser-Pereira (2016).
} 
Figure 2: China: balance of payments, current account, annual

(US\$ at current prices in millions)

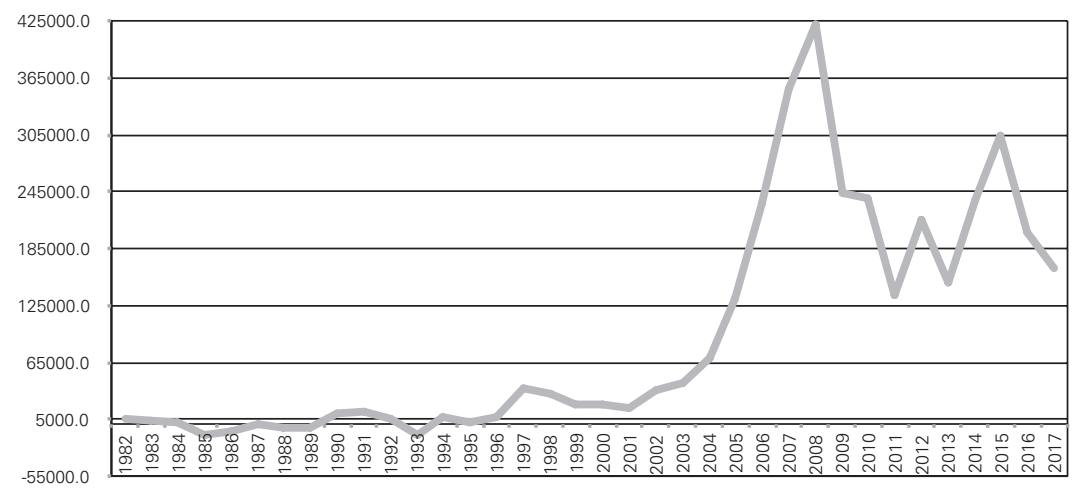

Source: Own elaboration from UnctadStat (2019).

It's important to notice that not only current account deficits were rare but also credit has been wisely used by Chinese Government as an instrument for industrial policy. During Chinese industrialization, there was a great transformation of Chinese financial system, which to this day is still very controlled by central Government. In 1985, the People's Bank of China became the Central Bank been responsible for regulation, while the big four state-owned banks - Agricultural Bank of China, Bank of China, China Construction Bank, Industrial and Commercial Bank of China - were responsible for commercial and development activities. In addition to the four major banks, the Chinese financial system already had over 35,000 rural credit cooperatives, about 1,000 urban credit cooperatives and more than 111 regional commercial banks. All this public financing structure had (and still has) the main objective to foster growth and extend credit to projects that enable the development of a modern industrial structure (Cintra, 2009).

With this structure and the decision to grant credit for production, it was possible to modernize and expand the existing industry. Not just credit was available, but also the real interest rate was adequate. As it is shown on Figure 3, throughout the whole period the real interest rate remained at reduced levels, around $2 \%$ p.y. Finally, we highlight that it is not enough that interest rates are low; it is essential that credit is available, and that industries do have access to them to finance their investments. Chinese state knew how to use their financial system to ensure that the credit would reach their companies; it didn't matter if they were state-owned Enterprises (SOEs), Town-ship and village enterprises (TVEs), joint-ventures or private companies.

Here we find another point of convergence between the policy adopted in China to foment their industrialization and what is proposed by the New Developmentalism: the theory suggests that the interest rate is a central variable for the country's development strategy and that it must be kept low to stimulate investment, exactly what happened in China during the period of 1980-2016. 


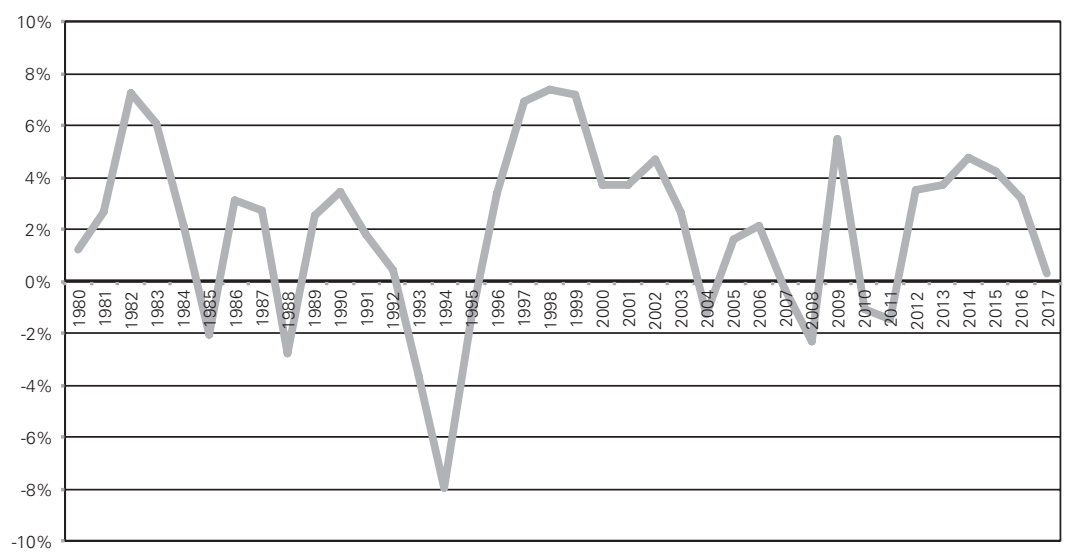

Source: Own elaboration from World Bank (2019).

In addition to the low real interest rate, several authors claim that the exchange rate was (and continues to be) used by China as an instrument of industrial policy. Cunha, Biancareli and Prates (2007, p. 529), for example, suggests that there is "a weak yuan diplomacy", in which management of the national currency is linked closely to the goal of preserving economic stability, growth and internal/ external policy.

Analyzing the exchange rate fluctuations, it's possible to perceive that Chinese state has managed to keep it constantly competitive. In 1984 there was a devaluation of the local currency (CHY) stimulating further production for external market in SEZs. Between 1980 and 1987, China devalued CHY/US\$ in 151\%; between 1987 and 1994, there was a new process of devaluation, reaching 55\%, maintaining the currency highly devaluated for more than a decade. In 2005, with great international pressure, China began to adopt the floating regime, administrating yuan based on a basket of currencies (Cunha, Biancareli \& Prates, 2007, p. 545). Figure 4 shows that, in spite of these changes, apparently, China has managed to keep a competitive exchange rate, using it as a tool to ensure competitiveness and development to the Chinese industry.

Exchange rate is a central price for the New-Developmental Theory; the analysis of the trajectory of exchange rate in China indicates another important convergence between Chinese industrialization and the strategy proposed by New Developmentalism. By keeping the exchange rate competitive, with a surplus on the balance of payments, Chinese Government ensures international competitiveness to companies installed in the country, allowing them to compete on equal footing in international market. As productivity of the domestic industry increases, the competitive exchange rate for industry would tend, in the long run, to free market exchange rate. In this way, the government could even, slowly, let their currency float towards this rate. However, what we see is that even though China could let their currency appreciate slowly with their productive gain - that has been positive 
Figure 4: Currency exchange rates (CHY/US\$), 1970-2017

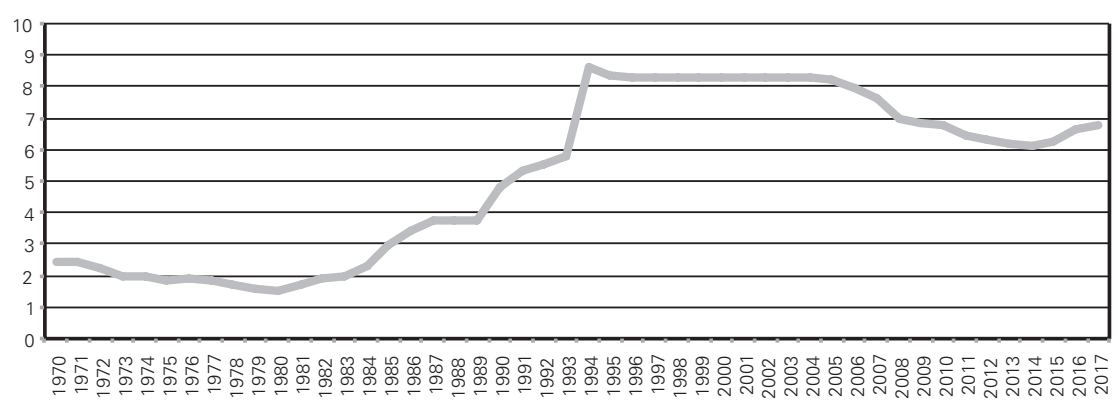

Source: Own elaboration from Unctad (2019).

for decades now -, they rather keep it devaluated as an effective instrument of industrial policy.

Since credit is available for companies that want to increase their productivity, with low real interest rates and a competitive exchange rate, the investment rate has remained high and ensured the strong growth of approximately $10 \%$ p.y. As Figure 5 shows, throughout the whole period, China kept their Gross Fixed Capital Formation over GDP (GFCF/GDP) at a rate above $25 \%$ - mostly above $30 \%-$, indicating that investment was the driver to growth. Since China experienced a long period with high investment rate, it can be assumed that Chinese industrialization followed another condition proposed by New-Developmental Theory: maintaining the rate of profit of companies in a level capable of encouraging investment in the long-term. Unfortunately, there is no data available to check what the profit rate of the industry in this period was but, if investment was kept high for more than three decades, we could suppose that their profit rate was at least satisfactory to stimulate companies to keep investing. That's what the New-Developmental Theory suggests: the nation-state should assure conditions for companies to have a satisfactory profit rate.

Two questions arise from what has been exposed so far. The first one is whether or not Chinese production structure has experienced a transformation towards more technologically advanced links in the productive chain, in other words: is growth materializing in productive sophistication? The second question, essential to think about the success of a development strategy, is if wages are growing with the increase in productivity and reducing inequalities. The New-Developmental Theory asserts that salaries and living standards of the population should grow with the increase of productivity.

The first question - if Chinese production structure has experienced a transformation towards more technologically advanced links in the productive chain could be analyzed based on the data of Chinese exports goods by technological intensity shown on Table 2 . While in $1985,35 \%$ of all Chinese exported goods came from the primary sector, and only $2.6 \%$ of high-tech goods; in 2005 more than a third came from the high-technology category, and only $4.4 \%$ from prima- 
Figure 5: Gross Fixed Capital Formation over Gross domestic product (GFCF/GDP), 1978-2017

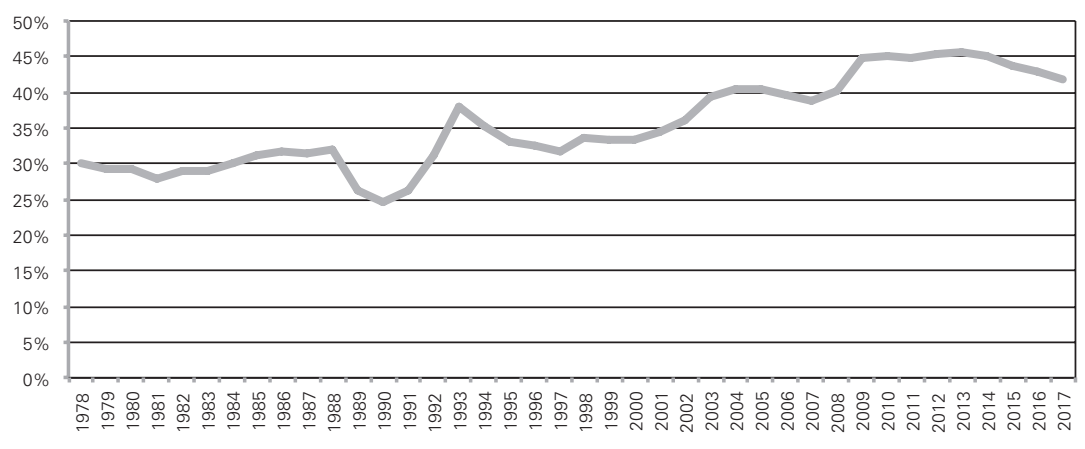

Source: Own calculation from Unctad (2019).

ry products. These data indicate that there was in fact a change in the Chinese productive structure towards more sophisticated and dynamic links in the production chain.

Table 2: Chinese exports by technological intensity, 1985-2005 (\%)

\begin{tabular}{cccccc}
\hline Year & $\begin{array}{c}\text { Primary } \\
\text { Products }\end{array}$ & $\begin{array}{c}\text { Based on } \\
\text { Natural } \\
\text { Resources }\end{array}$ & $\begin{array}{c}\text { Low } \\
\text { Technology }\end{array}$ & $\begin{array}{c}\text { Medium } \\
\text { Technology }\end{array}$ & $\begin{array}{c}\text { High } \\
\text { Technology }\end{array}$ \\
\hline 1985 & $35,10 \%$ & $13,50 \%$ & $39,80 \%$ & $7,70 \%$ & $2,60 \%$ \\
1987 & $25,10 \%$ & $10,30 \%$ & $47,40 \%$ & $11,30 \%$ & $4,40 \%$ \\
1989 & $17,90 \%$ & $8,40 \%$ & $51,20 \%$ & $14,70 \%$ & $6,70 \%$ \\
1991 & $12,90 \%$ & $7,30 \%$ & $55,80 \%$ & $15,20 \%$ & $7,90 \%$ \\
1993 & $9,90 \%$ & $6,40 \%$ & $57,10 \%$ & $15,40 \%$ & $10,40 \%$ \\
1995 & $7,50 \%$ & $6,80 \%$ & $53,60 \%$ & $16,90 \%$ & $14,20 \%$ \\
1997 & $6,40 \%$ & $6,60 \%$ & $51,20 \%$ & $17,00 \%$ & $17,80 \%$ \\
1999 & $5,40 \%$ & $6,30 \%$ & $48,50 \%$ & $17,20 \%$ & $21,50 \%$ \\
2001 & $4,90 \%$ & $6,20 \%$ & $45,60 \%$ & $17,90 \%$ & $24,40 \%$ \\
2003 & $4,30 \%$ & $6,10 \%$ & $42,50 \%$ & $18,50 \%$ & $27,50 \%$ \\
2005 & $4,40 \%$ & $8,30 \%$ & $31,50 \%$ & $22,00 \%$ & $33,20 \%$ \\
\hline
\end{tabular}

Source: Cunha e Xavier (2010, p. 494).

With regard to the second question, if wages are growing with the productivity, we considered the data from International Labour Organization (ILO) to measure productivity and earnings from employees. As Figure 6 shows from 1991 to 2016 productivity and employees earnings followed a very similar path, with great 
gain for both. We could say that productivity is growing due to its catching-up and that this process is also creating better living conditions for Chinese population with greater earnings for employees.

The data presented lead us once again to the conclusion that the theoretical framework proposed by the New Developmentalism is appropriate to understand the success of Chinese catching-up. The theory suggests that salaries must be compatible with a satisfactory rate of profit and should grow with productivity. What Figure 6 shows is that that is exactly what is happening in China.

Figure 6: Chinese labor productivity and average monthly earnings of employees, constant 2011 international US\$ in PPP

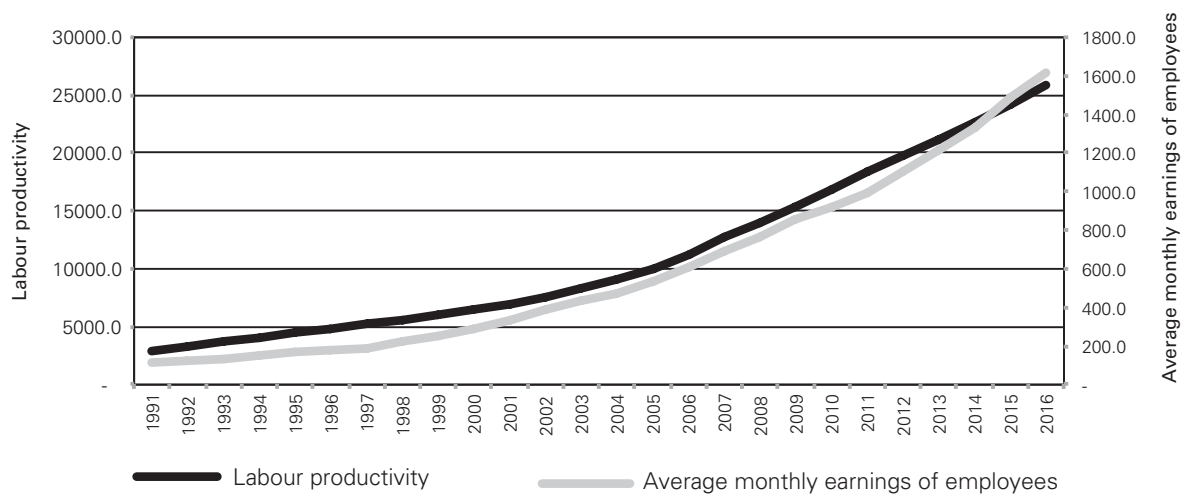

Source: Own elaboration from ILOStat (2019).

Note: Labour productivity is calculated by Intenational Labour Organization (ILO) using data on GDP (in constant 2011 international dollars in PPP) derived from the World Development Indicators database of the World Bank. To compute labour productivity as GDP per worker, ILO uses its estimation for total employment. For the average monthly earnings of employees ILO uses data on the average monthly earnings converted to constant 2011 U.S. dollars are converted using 2011 purchasing power parities (PPPs); from 1991 to 2005 the table shows data from an Establishment Survey and from 2005 to 2016 uses Employment office records.

There remains one final price to be analyzed: the inflation rate. The New-Developmental Theory proposes that inflation rate should be low. The following graphic shows official Chinese inflation rate for the period of 1980 to 2017. We can see that, in spite of the high GDP growth, inflation rate has mostly been under control, varying in the range of $0 \%$ to $5 \%$, with some peaks in the decades of 80 and 90 .

In that way, once again, the Chinese development strategy is aligned to the theoretical framework proposed by theory, since inflation rate has also been controlled during almost the whole period of catching-up. 
Figure 7: China: Inflation, consumer prices (annual \%)

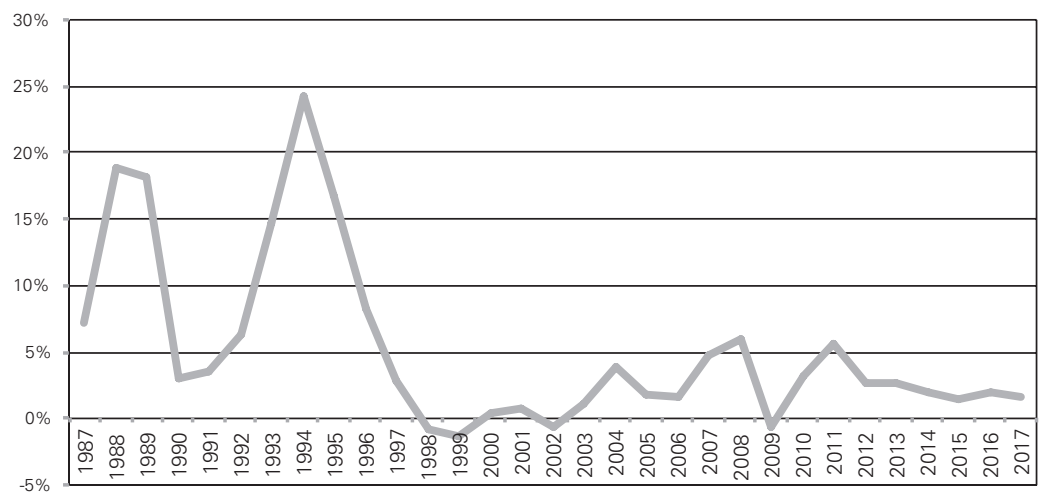

Source: Own elaboration from World Bank (2019)

\section{CONCLUSION}

Through a synthesis of Chinese industrialization, I presented some points of convergence between Chinese industrialization and what is the proposed by the New-Developmental Theory as a framework for middle-income countries to achieve development.

During Mao Zedong's Era (1949-1976), China was able to create their nation-state, realize their primitive accumulation and their industrial/capitalist revolutions. After 1978, with a very successful strategy, was able to obtain an average growth rate of $10 \%$ p.y, a growth rate dreamed by most middle-income countries. In order to do so, China kept right the five macroeconomic prices, exactly what is proposed by the New-Developmental Theory. The inflation rate was low in almost the entire period; the real interest rate remained at the level of around $2 \%$ per year; the exchange rate was kept depreciated when compared to the free market as a way to guarantee that companies installed in the country were internationally competitive; corporate profits were probably at least satisfactory, because the investment rate remained high throughout this process; and, finally, wages have been increasing with the increase in productivity.

Through this brief summary of the Chinese industrialization, we concluded that the New Developmentalism theoretical framework is appropriate to interpret the development strategies adopted by China in its catching-up process. Based on the Chinese industrialization analysis we could start a wider reflection on how we could use the proposals of the New-Developmental Theory to investigate, in addition to the success, failure, and necessary corrections that could be made on the path of development for middle-income countries. 


\section{REFERENCES}

Bresser-Pereira, Luiz Carlos (2019) "From classical developmentalism and post-Keynesian macroeconomics to new developmentalism”, Brazilian Journal of Political Economy 39(2) April: 187-210.

Bresser-Pereira, Luiz Carlos and Paulo Gala (2008) "Foreign savings, insufficiency of demand, and low growth”, Journal of Post Keynesian Economics, 30 (3), Spring 2008: 315-334.

Bresser-Pereira, Luiz Carlos; Oreiro, José Luis; Marconi, Nelson. (2016) Macroeconomia Desenvolvimentista. Rio de Janeiro: Campus/Elsevier.

Bresser-Pereira, Luiz Carlos. (2017a) "The economics and political economy of new-developmentalism”, Working Paper 464, São Paulo: EESP/FGV, nov/2017.

Bresser-Pereira, Luiz Carlos. (2017b) "The two forms of capitalism: developmentalism and economic liberalism", Brazilian Journal of Political Economy, 37(4), oct/2017.

Bresser-Pereira, Luiz Carlos. (2018) "Neutralizing the Dutch disease”, Working Paper 476, São Paulo: EESP/FGV, may/2018.

China Statistical Yearbook. (1999) Available online at: http://www.stats.gov.cn/english/statisticaldata/ yearlydata/YB1999e/index1.htm [Accessed abr/2019].

Cintra, Marcos A. M. (2009) As instituições financeiras de fomento e o desenvolvimento econômico: as experiências dos EUA e da China. In: Ferreira, F. R. M.; Meirelles, B. B. Ensaios sobre economia financeira. Rio de Janeiro: BNDES, 2009.

Cunha, André M.; Biancareli, André M.; Prates, Daniela M. (2007) “A diplomacia do Yuan Fraco", Revista de Economia Contemporânea, Rio de Janeiro, 11(3), dec/2007.

Cunha, Samantha F.; Xavier, Clésio L. (2010) "Fluxos de investimento direto externo, competitividade e conteúdo tecnológico do comércio exterior da China no início do século XXI", Brazilian Journal of Political Economy, 30(3), sep/2010.

ILOS (2019) International Labour Organization. Available online at: https://www.ilo.org/ilostat/faces/ wcnav_defaultSelection?_afrLoop $=1759954406726250 \&$ \&afrWindowMode $=0 \&$ \&_afrWindow Id=null\#!\%40\%40\%3F_afrWindowId\%3Dnull\%26_afrLoop\%3D1759954406726250\%26_ afrWindowMode\%3D0\%26_adf.ctrl-state\%3D4cbex72dp_158 [Accessed abr/2019].

Jabbour, Elias; Dantas, Alexis. (2017) "The political economy of reforms and the present Chinese transition”, Brazilian Journal of Political Economy. 37(4), dec/2017.

Leão, Rodrigo P. F. (2010) O padrão de acumulação e o desenvolvimento econômico da China nas últimas três décadas: uma interpretação. Dissertação de Mestrado, Pós-Graduação em Economia, Instituto de Economia da Unicamp, Universidade Estadual de Campinas, Campinas.

Masieiro, Gilmar. (2006) "Origens e desenvolvimento das Township and Village Enterprises (TVEs) chinesas”, Brazilian Journal of Political Economy, 26(3), sep/2006.

Medeiros, Carlos A. (1999) "Economia política do desenvolvimento recente da China”, Brazilian Journal of Political Economy, 19(3), sep/1999.

Milaré, Luís Felipe L.; Diegues, Antônio Carlos. (2012) “Contribuições da era Mao Tsé-Tung para a industrialização chinesa”. Revista de Economia Contemporânea, 16(2), jul/2012.

Milaré, Luís Felipe L.; Diegues, Antônio Carlos. (2015) “A industrialização chinesa por meio da tríade autonomia-planejamento-controle”, Leituras de Economia Política, 22(1), jan/2015.

Pagotto, Claudete. (2006) "Apontamentos acerca das principais formas de cooperação na China entre 1950 e 1966”, Novos Rumos, 46(21), 2006.

Unctad (2019) United Nations Conference on Trade and Development Data Center. Available online at: https://unctadstat.unctad.org/wds/ReportFolders/reportFolders.aspx?sCS_ChosenLang=en [Accessed abr/2019].

World Bank (2019) World Bank Open Data. Available online at: https://data.worldbank.org/ [Accessed $\mathrm{abr} / 2019]$. 